\title{
Improving Students' Learning Result Using Numbered Heads Together Model
}

\author{
Mauliza* \\ Department of Chemistry Education, Faculty of Teacher Training and Education, Samudra University, Kota Langsa, 24416, Indonesia \\ mauliza@unsam.ac.id \\ ${ }^{*}$ Corresponding Author \\ Whatsapp Number [+62-85361091239]
}

How to Cite: Mauliza, M. (2020). Improving Students' Learning Result Using Numbered Heads Together Model. International Journal for Educational and Vocational Studies, 2(3), 301-303. DOl: https://doi.org/10.29103/ijevs.v2i3.2445

\section{ARTICLE HISTORY}

Received: 23 February 2020

Revised: 28 February 2020

Accepted: 8 March 2020

\section{KEYWORDS}

Learning Outcomes;

Health and Safety;

Laboratory Material;

Numbered Heads Together Model;

\begin{abstract}
This study aimed to determine the increase in student cognitive learning outcomes within material of occupational health and safety at the laboratory by implementing the Numbered Heads Together model, as well as obtains the students' perspective toward the implementation of the model. This research was conducted with a quasi-experimental method through one group pretest-posttest design conducted at University of Samudra. Data collection was done by pretest and posttest to find the escalation in cognitive learning outcomes, as well as a questionnaire to determine student responses to the numbered heads together learning model. The average value of $\mathrm{N}$-gain cognitive learning outcomes was 0.51 , which was categorized as moderate category; it meant that in general, there was an increase in cognitive learning outcomes of students. Descriptively, students also gave a positive response toward implementation of the Numbered Heads Together model, so it can be concluded that learning with the Numbered Heads Together Model can improve student cognitive learning outcomes.
\end{abstract}

This is an open access article under the CC-BY-SA license.

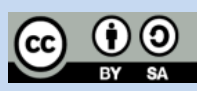

\section{INTRODUCTION}

Learning process is one of the most influencing factors in the education unit. All changes, problems and challenges that arise in the world of education must be able to be faced with an open attitude and creative thinking; therefore, education is significant for humans to help develop their potencies. An active interaction between students and educators is needed in the teaching and learning process (Widiawati et al., 2014). The interaction makes the learning process more meaningful.Thus, the objectives of learning can be achieved as maximum as possible.

The interaction between educators and students also occurs at the tertiary level, namely between lecturers and students. Successful learning is demonstrated by the mastery of lecture material by students with a level of mastery of the concept of the material usually expressed by value (Fransisca, 2019). Slavin (2011) states that by using mutual discussion and collaboration with friends and interdependence, in the structure of tasks, goals and prizes, will ease students understanding concepts that are classified as difficult. The purpose of education in learning can be achieved in one way, namely the application of effective learning models. Learning models that are considered effective to be applied in the learning process are cooperative models, one of which is the numbered heads together. Jacobsen (2009) states that the Numbered Head Together (NHT) is a learning model that involves more students in discussions to understand the material in a lesson and evaluates the extent of students' understanding of the material. This model can be applied to all subjects and for all levels of students. In this learning model, students are grouped into learning groups consisting of students who work together in a learning activity. Every student in one group is expected to be able to work together and take responsibility both to themselves and the group.

Some previous studies mentioned that, the NHT type of cooperative learning model affected critical thinking skills with an effect size index of 0.7 with a percentage of $76 \%$ better than conventional learning (Wati and Fatimah, 2016). The NHT learning model also has an effect on the ability to remember students by $24.03 \%$ higher than conventional learning (Nursyamsi and Corebima, 2016). In addition, the average student learning outcomes using the NHT model is greater than the use of the TPS model (Rahayu and Suningsih, 2018). Laboratory Basic Engineering course is one of the basic courses that must be attended by first semester students with a total weight of 
two SKS. One of the material taught is Occupational Health and Safety in the Laboratory.

Based on the results of preliminary observations on the previous material, information was obtained that there were several obstacles in which many of the students were less motivated so that they had difficulty understanding the learning of Basic Laboratory Techniques, which resulted in low learning outcomes. Therefore, efforts are needed to make changes and improvements to learning strategies that can lead students to want to be actively involved in learning activities. The change chosen in this study was the application of the Numbered Head Together learning model.

\section{MATERIALS AND METHODS}

This study was done as a quasi-experimental research. The design used in this study was one group pretest posttest design (Fraenkel et al., 2012). This research consists of three stages, namely: (1) giving a test at the beginning of learning (pretest); (2) the implementation of learning with the model numbered heads together; and (3) giving tests at the end of learning (posttest).

This study was conducted in the Department of Biology Education at Samudra University. It was done during the teaching of health and safety material within the course of Technics in Laboratory during the academic year of $2015 / 2016$.

\subsection{Data Collection}

The samples in this study were 21 students who took
Laboratory Engineering courses in the 2015/2016 academic year. Data were collected using test and non-test instruments.Improved student cognitive learning outcomes were measured using a test instrument in the form of a pretest and posttest.Student responses toward learning using the numbered heads together model were collected using a non-test instrument in the form of a questionnaire sheet.

\subsection{Data Analysis}

The research data in the form of pretest and posttest values were analyzed by calculating the normalized gain ( $\mathrm{N}$-gain). According to Fraenkel (2012) the increase that occurs after learning is carried out can be calculated with the following formula:

$$
g=\frac{\text { posttests score }- \text { pretest scone }}{\text { mximum score }- \text { initial score }(\text { pretest })}
$$

The responses toward questionnaires were analyzed using descriptive technic as a triangulation toward the result of statistical data.

\section{RESULTS AND DISCUSSION}

\subsection{Statistical Data Analysis}

The score for pretest and posttest was described on Table 1, the $\mathrm{N}$-gain was in table 2 and students' responses was in table 3 .

Table 1.Score for Pretest and Posttest

\begin{tabular}{ccc}
\hline Statistical Parameter & Pretest & Posttest \\
\hline Number of Students & 21 & 21 \\
Lowest Score & 75 & 95 \\
Highest Score & 25 & 60 \\
Average & 46.16 & 74.52 \\
\hline
\end{tabular}

Table 2. N-gain for Learning Result

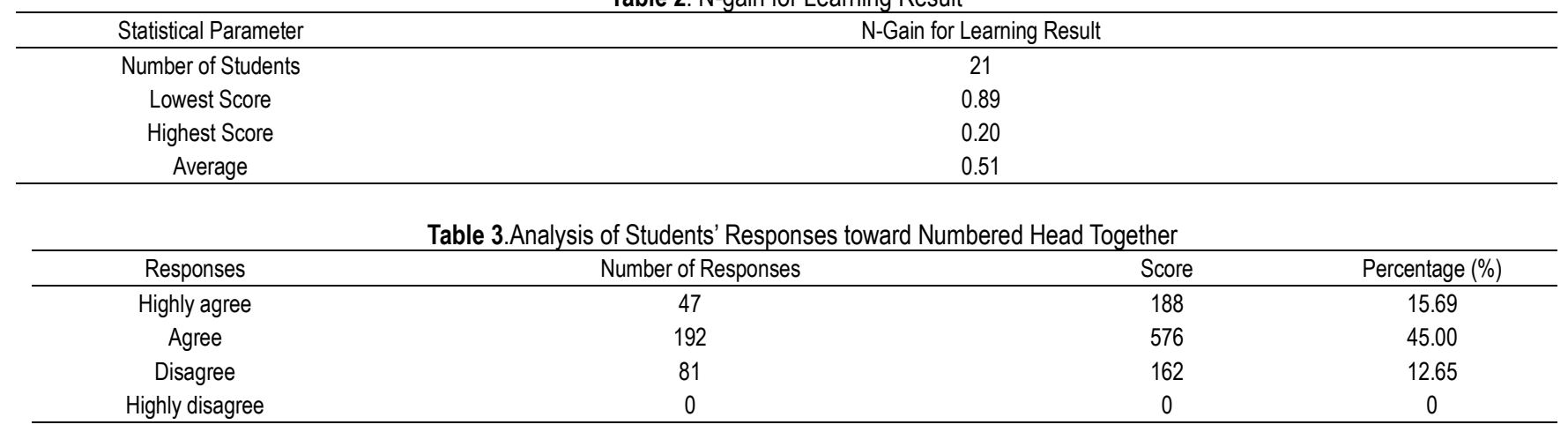

\subsection{Discussion}

and then given a posttest. The average value of student cognitive learning outcomes at the time of the pretest is

The initial state of the sample is measured by being given a 46.19 then an increase in the value at the posttest is 74.52 pretest, then given a numbered heads together learning, can be seen based on Table. This is consistent with the 
opinion of Mulyana et al. (2016) which said that learning outcomes increased by $89.65 \%$ after the application of the NHT model. The similar result was also obtained by Wijayantiet.al (2017), which indicated improvement toward learning by implementing NHT.

Increased student cognitive learning outcomes achieved can be determined by the calculation of $\mathrm{N}$-gain. Based on Table. 2 obtained the highest $\mathrm{N}$-gain value is 0.89 and the lowest is 0.20 . The results of the average $\mathrm{N}$-gain is 0.51 included in the medium category. This means that in general there is an increase in student cognitive learning outcomes after learning about occupational health and safety material in the laboratory with the numbered heads together model. This is consistent with the opinion of Ernawati (2015) who said that learning outcomes in the Biochemistry course and student activities in learning have increased after the use of the numbered heads together model. And Sulfiani (2016), also said that there was an increase in student learning outcomes after the application of the cooperative learning model numbered heads together.

Based on the analysis of the questionnaire responses of students in Table 3, a percentage calculation was made of each response. The questionnaire sheet consisted of 16 statement items that were filled out by 21 students, based on the results of the analysis obtained answers that strongly agree as much as $15.69 \%$, agree as much as $45.00 \%$, disagree as much as $12.65 \%$. The percentage of all questionnaire answers obtained was $73.34 \%$, so that it was included in the agreed criteria and it was generally concluded that the students agreed if the numbered heads together learning model was applied.

\section{CONCLUSION}

Based on the results of research and discussion it can be concluded that learning laboratory techniques with the implementation of the numbered heads together model can improve student cognitive learning outcomes, and overall the implementation of the numbered heads together model gets a positive response from students.

\section{REFERENCES}

Ernawati, T. (2015). Penerapan Model Pembelajaran Numbered Heads Together (NHT) dalam Upaya untuk Meningkatkan Keaktifan dan Hasil Belajar Mahasiswa Prodi Pendidikan IPA UST Yogyakarta Tahun 2013/2014. J.Pijar MIPA X(1):26-30.

Fraenkel, J.R., N. E. Wallen, dan H. H. Hyun. (2012). How to Design and Evaluate Research in Education. New York: McGraw-Hill.

Fransisca, Y. (2019). Meningkatkan Hasil Belajar Mahasiswa pada Mata Kuliah Rangkaian Listrik menggunakan Model Pembelajaran Direct Instruction dan Software Circuit Wizard. Journal of Vacational and Technical Education 01(01): 7:19.

Jacobsen, D. A., P. Eggen, dan D. Kauchak. (2009). Methods for Teaching: Metode-Metode Pengajaran Meningkatkan Belajar Peserta didik TK-SMA. Yogyakarta: Pustaka Pelajar.

Mulyana, M.A., N. Hanifah, dan A.K. Jayadinata. (2016). Penerapan Model Kooperatif Tipe Numbered Heads Together (NHT) untuk Meningkatkan Hasil Belajar Siswa pada Materi Kenampakan Alam dan Sosial Budaya. Jurnal Pena Ilmiah 1(1):331-340.

Nursyamsi, S.Y. dan A.D. Corebima. (2016). The Effect of Numbered Heads Together (NHT) learning Strategi on the Retention of Senior High School Students in Muara Badak, East Kalimantan, Indonesia. European Journal of Education Studies 2(5):47-58.

Rahayu, S. dan A.Suningsih. (2018). The Effects of Type Learning Model Nembered Head Together and Think Pair Share. International Journal of Trends in Mathematics Education Research 1(1):19-21.

Slavin, A. (2011). Pembelajaran Kooperatif TipeNHT, Terjemahan.Jakarta: RinekaCipta.

Sulfiani, R. (2016). Application of CooperativeLearning Model Numbered Head Together (NHT) to Improve Student Learning Outcomes Chemistry Class XI IPA 1 SMAN 3 Watampone (Studies on thetopicStructure of Atoms, Periodic System of ElementsandMoleculesForm). Jurnal Chemica 17(1):1-13.

Wati, W. dan R. Fatimah. (2016). EffectSize Model Pembelajaran Kooperatif Tipe Numbered Heads Together (NHT) terhadap Kemampuan Berpikir Kritis Siswa pada Pembelajaran Fisika. Jurnal Ilmiah Pendidikan Fisika Al-BiRuNi 05(2):213-222.

Widiawati, R., N. Kurnia, dan E. Ariyati. (2014). Penerapan Pembelajaran Kooperatif STAD pada Materi Archae baca teriadan Eubacteria terhadap Hasil Belajar Siswa. Artikel Penelitian. Pontianak: Program Studi Pendidikan Biologi FKIP Universitas Tanjungpura.

Wijayanti, N.W., Roemintoyo, dan T. Murwaningsih. (2017). The Impact of Numbered Heads Together Model on the Learning Outcomes of Science Viewed from Students' Self Regulated Learning. Journal of Education and Learning 11(3):257-261. 